29 Painter, N. S., Rendiconti Romani di Gastro-Enterologia, 1972, 4, 35. ${ }^{30}$ Petrie, J. C., Needham, C. D., and Gillanders, L. A., British Medical fournal, 1972, 2, 78.

31 Bohrer, S. P., New England fournal of Medicine, 1965, 272, 695.

32 Milton-Thompson, G. J., and Lewis, R., personal comminication, 1971.
33
s4
Hill, M. J., et al., Lancet, 1971, $1,95$.

${ }^{35}$ Hill, M. J., Goddard, P., and Williams, R. E. O., Lancet, 1971, 2, 472.

${ }^{36}$ Hughes, L. E., Gut, 1969, 10, 336.

37 Lancet, 1969, 2, 361 .

\title{
Changes of Blood Pressure, Renin, and Angiotensin after Bilateral Nephrectomy in Patients with Chronic Renal Failure
}

\author{
A. MEDINA, P. R. F. BELL, J. D. BRIGGS, J. J. BROWN, A. FINE, A. F. LEVER, J. J. MORTON, \\ A. M. PATON, J. I. S. ROBERTSON, M. TREE, M. A. WAITE, R. WEIR, J. WINCHESTER
}

British Medical fournal, 1972, 4, 694-696

\section{Summary}

Circulating levels of renin, angiotensin $I$, and angiotensin II were increased in six patients with chronic renal failure and hypertension uncontrolled by dialysis and hypotensive drugs. Lower and often normal levels were found in 10 patients whose blood pressure was controlled by dialysis treatment. For a variety of reasons all patients were subjected to bilateral nephrectomy. The logarithm of the decrease in plasma concentrations of renin and angiotensin II was significantly related to the fall of blood pressure after operation. Plasma renin concentration correlated significantly with blood angiotensin I concentration and with plasma angiotensin II in samples taken before and after nephrectomy. Renin, angiotensin $I$, and angiotensin II were measurable in samples of blood taken 48 hours or more after the operation.

\section{Introduction}

Blood pressure is often increased in patients with chronic renal failure. Two abnormal processes seem to be involvedsodium retention with increased cardiac output, and raised renin with increased peripheral resistance. Although both abnormalities are sometimes present together, sodium retention is the predominant feature in most patients. When this is so blood pressure can usually be controlled if the excess sodium is eliminated by regular dialysis treatment and dietary sodium

Medical Research Council Blood Pressure Unit, Western Infirmary, Glasgow G11 6NT

A. MEDINA, M.D., Clinical Scientist

J. J. BROWN, M.B., F.R.C.P., Consultant Physician

A. F. LEVER, M.B., F.R.C.P., Consultant Physician

J. J. MORTON, PH.D., Scientist

J. I. S. ROBERTSON, M.B., F.R.C.P., Consultant Physician

M. TREE, B.SC., PH.D., Technical Officer

M. A. WAITE, M.B., M.R.C.P., Senior Medical Registrar

R. WEIR, M.B., M.R.C.P., Senior Medical Registrar

Renal Unit, Western Infirmary, Glasgow G11 6NT

J. D. BRIGGS, M.B., M.R.C.P., Consultant Physician

A. M. PATON, M.B., M.R.C.P., Medical Registrar

Department of Surgery, Western Infirmary, Glasgow G11 6NT

P. R. F. BELL, M.D., F.R.C.s., Consultant Surgeon

Renal Unit, Stobhill Hospital, Glasgow N.1

A. FINE, M.B., M.R.C.P., Medical Registrar

Renal Unit, Royal Infirmary, Glasgow

J. F. WINCHESTER, M.B., M.R.C.P., Medical Registrar restriction. In the smaller group with raised renin removal of sodium usually fails to control blood pressure, renin increases further, and bilateral nephrectomy may be necessary to control severe hypertension (Toussaint et al., 1966; Blumberg et al., 1967; Onesti et al., 1968; Brown et al., 1969, 1971; Gleadle et al., 1969; Safar et al., 1970; Stokes et al., 1970; Wilkinson et al., 1970; Ledingham, 1971; Bianchi et al., 1972; Lazarus et al., 1972; Verniory et al., 1972).

The object of the study described here was to assess the relation between changes of blood pressure and changes in circulating levels of renin, angiotensin I, and angiotensin II after bilateral nephrectomy in chronic renal failure.

\section{Patients and Methods}

Altogether, 16 patients were studied. All had end-stage chronic renal failure needing regular dialysis as maintenance treatment. Creatinine clearance was below $5 \mathrm{ml} / \mathrm{min}$ in each case. The interval between the onset of regular dialysis and bilateral nephrectomy varied greatly (see table). Except in cases with polycystic disease, the kidneys removed at operation were shrunken and often showed histological evidence of inflammatory and hypertensive change. The primary diagnoses listed in the table were, therefore, based on a combination of clinical and pathological observations.

Diastolic blood pressure taken in the lying position before dialysis was used to classify patients into the following groups.

Group 1.-In six patients it proved impossible to reduce average diastolic blood pressure below $110 \mathrm{~mm} \mathrm{Hg}$ in the month

Clinical and Pathological Data in the 16 Patients Under Study

\begin{tabular}{|c|c|c|c|c|}
\hline & $\begin{array}{l}\text { Case } \\
\text { No. }\end{array}$ & $\begin{array}{l}\text { Age and } \\
\text { Sex }\end{array}$ & $\begin{array}{c}\text { Duration of } \\
\text { Renal Dialysis } \\
\text { Before } \\
\text { Nephrectomy }\end{array}$ & $\begin{array}{c}\text { Renal } \\
\text { Lesion }\end{array}$ \\
\hline Group 1 & $\begin{array}{l}1 \\
2 \\
3 \\
4 \\
5 \\
6\end{array}$ & $\begin{array}{l}32 \mathrm{M} . \\
35 \mathrm{M} . \\
32 \mathrm{M} . \\
21 \mathrm{M} . \\
20 \mathrm{M} . \\
24 \mathrm{~F} .\end{array}$ & $\begin{array}{l}4 \text { months } \\
1 \text { month } \\
2 \text { weeks } \\
8 \text { months } \\
1 \text { week } \\
4 \text { months }\end{array}$ & $\begin{array}{l}\text { M.H. } \\
\text { M.H. } \\
\text { M.H. } \\
\text { G.N. } \\
\text { G.N. } \\
\text { P.N. }\end{array}$ \\
\hline Group 2 & $\begin{array}{r}7 \\
8 \\
9 \\
10 \\
11 \\
12 \\
13\end{array}$ & $\begin{array}{l}29 \mathrm{M} . \\
37 \mathrm{M} . \\
17 \mathrm{~F} \\
25 \mathrm{M} . \\
28 \mathrm{~F} . \\
33 \mathrm{M} .\end{array}$ & $\begin{array}{l}2 \text { months } \\
2 \text { months } \\
9 \text { months } \\
5 \text { months } \\
1 \text { year } \\
2 \text { months } \\
2 \text { months }\end{array}$ & $\begin{array}{l}\text { G.N. } \\
\text { P.N. } \\
\text { G.N. } \\
\text { G.N. } \\
\text { G.N. } \\
\text { G.N. }\end{array}$ \\
\hline Group 3 & $\begin{array}{l}14 \\
15 \\
16\end{array}$ & $\begin{array}{l}\text { 43M. } \\
\text { 33F: } \\
\text { 42F. }\end{array}$ & $\begin{array}{l}6 \text { months } \\
6 \text { months } \\
2 \text { months }\end{array}$ & $\begin{array}{l}\text { P.K. } \\
\text { P.N. } \\
\text { P.K. }\end{array}$ \\
\hline
\end{tabular}

Group $1=$ uncontrolled hypertension, group $2=$ controlled hypertension, and group $3=$ normal blood pressure. M.H. $=$ Malignant-phase hypertension. G.N. =
Glomerulonephritis. P.N. = Pyelonephritis. P.K. = Polycystic kidney. 
before bilateral nephrectomy. The therapeutic regimen used was a combination of dietary sodium restriction, removal of sodium and water by haemodialysis, and hypotensive drugs (Brown et al., 1969, 1971). Bilateral nephrectomy was, therefore, undertaken in each as a means of reducing blood pressure. Case 5 was dialysed for only one week before operation because of an associated microangiopathic haemolytic anaemia. Average diastolic blood pressure in this man was $118 \mathrm{~mm} \mathrm{Hg}$ in the month before operation and mean plasma renin concentration, the lowest in the group, was 16.7 units/litre.

Group 2.- In seven patients average diastolic blood pressure, previously greater than $110 \mathrm{~mm} \mathrm{Hg}$ was reduced to levels less than this by dialysis and dietary sodium restriction in the month before operation. In two of the seven cases, hypotensive drugs were given in addition. Bilateral nephrectomy was undertaken in the patients of this group in preparation for renal transplantation.

Group 3.-In three patients average diastolic blood pressure remained below $100 \mathrm{~mm} \mathrm{Hg}$ before and during dialysis treatment. Here again, bilateral nephrectomy was undertaken in preparation for transplantation.

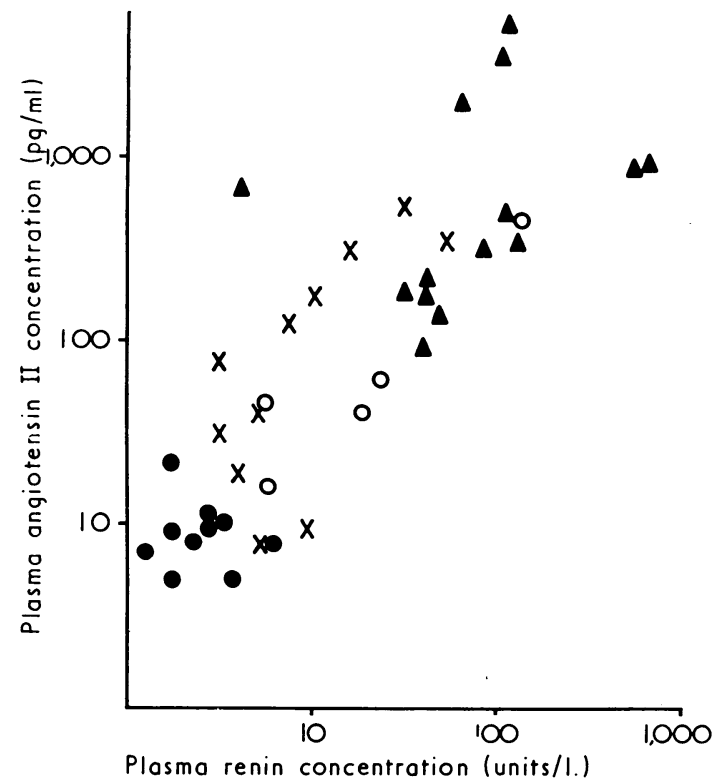

FIG. 1-Relation between plasma concentrations of renin and angiotensin II in patients with chronic renal failure (using logarithmic values, $\mathbf{r}=$ $+0.740, \mathrm{P}<0.001)$. $\Delta=$ measurements from patients of group 1 with uncontrolled hypertension. $O=$ patients with controlled hypertension (group 2) or normal blood pressure (group 3). $\mathbf{X}=$ samples taken in the 48-hour period after bilateral nephrectomy. $\dot{0}=$ samples taken after an interval greater than this.

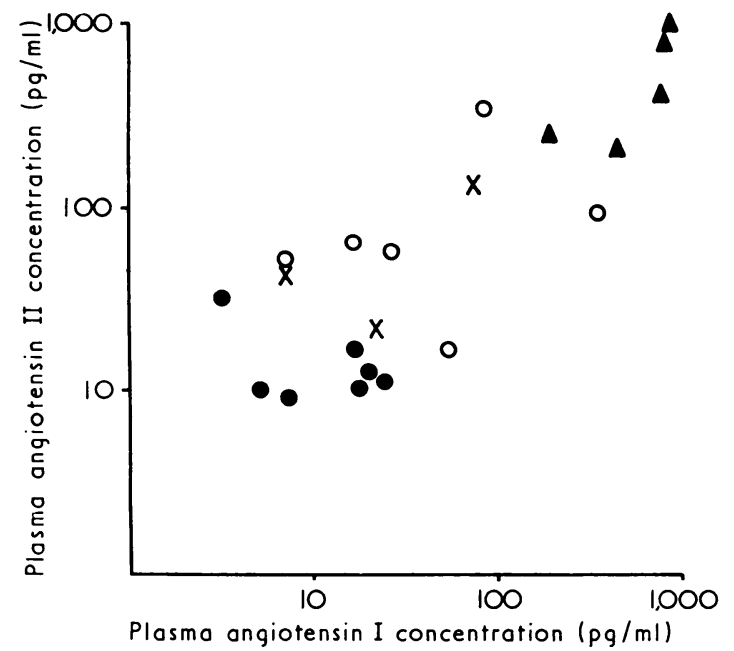

FIG. 2-Relation between blood angiotensin I and plasma angiotensin II in patients with chronic renal failure (using the logarithm of the angiotensin values, $r=+0.784, P<0.001)$. Symbols as in Fig. 1 .

\section{MEASUREMENTS}

Plasma renin concentration was measured by the method of Brown et al. (1964), plasma angiotensin II by the method of Düsterdieck and McElwee (1971), and blood angiotensin I by the method of Waite (1972a, 1972b). Not all measurements were made in every patient. For the analysis shown in Figs. 3 and 4 average preoperative values (of lying diastolic pressure, renin, angiotensin I, and angiotensin II) were the mean of all estimates made in the four weeks before operation. Average postoperative values were the mean of all measurements in the six months after operation excluding the first 23 hours.

\section{Results}

Circulating levels of renin, angiotensin I, and angiotensin II correlated closely in the patients in this study. The highest values encountered before operation were in patients with severe hypertension uncontrolled by renal dialysis and hypotensive drugs (Fig. 1 and 2). The greatest decrease of blood pressure, renin, angiotensin I, and angiotensin II also occurred in these patients after operation (Figs. 3 and 4). Renin and angiotensin levels were normal or less markedly raised before operation in patients whose diastolic blood pressure was either normal throughout (group 3) or reduced by treatment to less than $110 \mathrm{~mm} \mathrm{Hg}$ (group 2). As would be expected from this, changes of blood pressure, renin, and angiotensin after operation were generally less noticeable in the patients of groups 2 and 3. Including data from all groups there were significant correlations

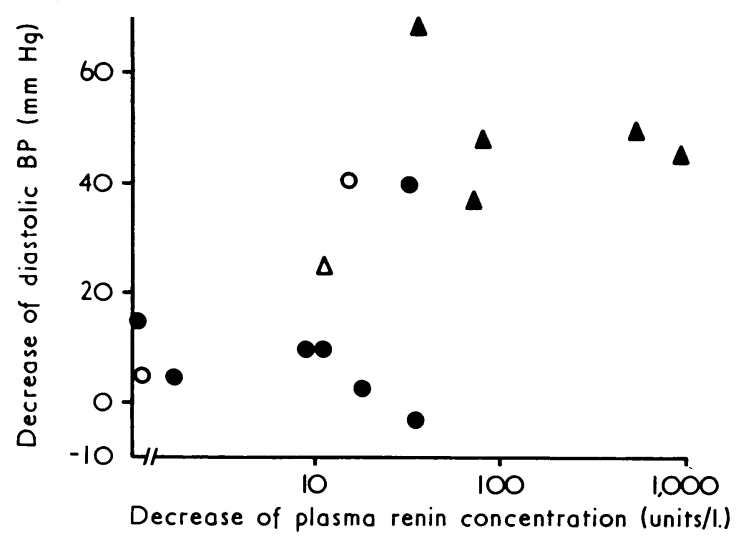

FIG. 3-Correlation between decrease of blood pressure and decrease of plasma renin concentration in 15 patients subjected to bilateral nephrectom (using logarithm of renin values, $r=+0.570, P<0.02) . \Delta=$ patients with previously uncontrolled hypertension (group 1). $=$ patients of group 2 . $\mathrm{O}=$ patients of group 3 . (See methods.)

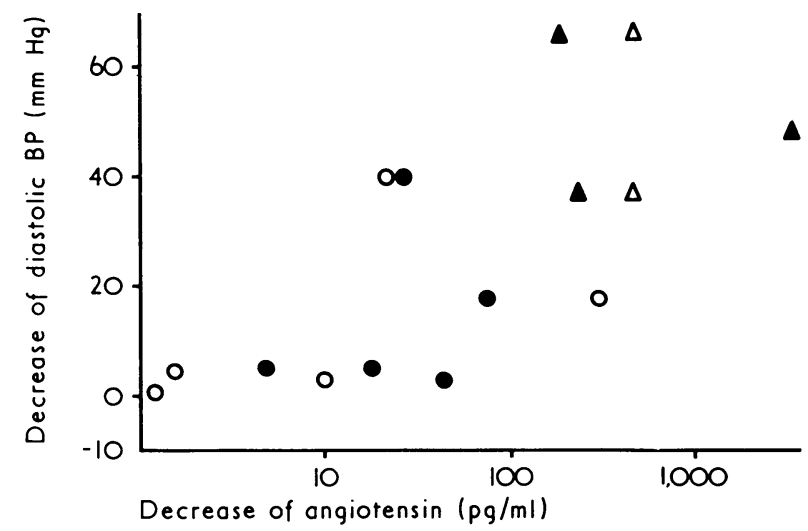

FIG. 4-Decrease of blood pressure and blood angiotensin I concentration are represented by open symbols (using the logarithm of angiotensin concentration, $\mathrm{r}=+0.665, \mathrm{P} 0.05-0 \cdot 1)$ after bilateral nephrectomy. Decrease concentration, $\mathrm{r}=+0 \cdot 665, \mathrm{P} 0 \cdot 05-0 \cdot 1)$ after bilateral nephrectomy. Decrease
of blood pressure and plasma angiotensin II are shown as solid symbols (using the logarithm of angiotensin concentration, $r=+0.640, P<0.05$ ). (using the logarithm of angiotensin concentration, $r=+0.640, P<0.05$ ).
Patients with previously intractable hypertension are shown as triangles; patients with lower levels of blood pressure (groups 2 and 3 ) as circles or dots. 
between the reduction of diastolic pressure and the logarithm of the change of renin and angiotensin II (Figs. 3 and 4).

Renin, angiotensin I, and angiotensin II were measurable in all samples of blood taken 48 hours or more after bilateral nephrectomy (Figs. 1, 2, and 5). Plasma renin concentration showed no tendency to decline in the two-year period after operation (Fig. 5).

Thirteen of the 16 patients were alive an average of 30 months after bilateral nephrectomy. Nine of the 13 had a renal transplant.

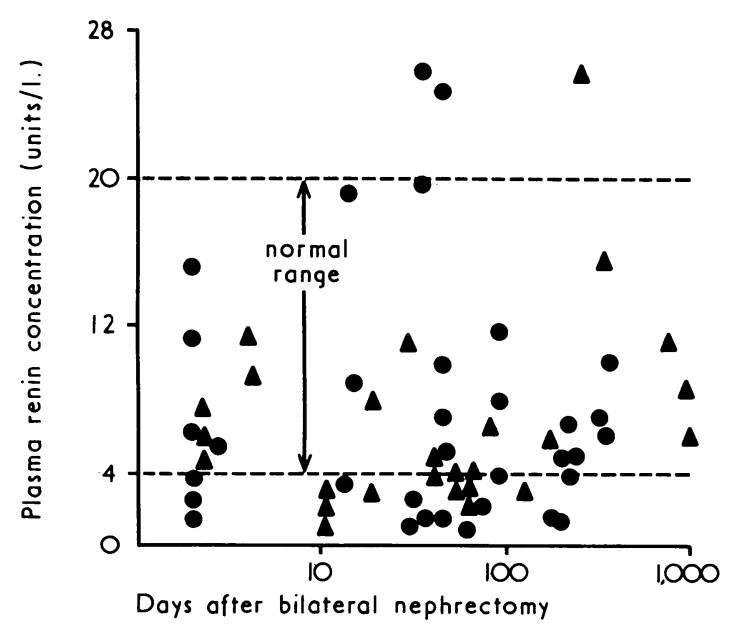
FIG. 5-Plasma renin concentration in male $(\underset{\text { S }}{)}$ and female $(\boldsymbol{\Delta})$ patients at varying intervals after bilateral nephrectomy. The smallest amount of renin substrate used. The range of renin found in normal subjects is shown by the substrate used. The
horizontal bars.

\section{Discussion}

It is known that bilateral nephrectomy can reduce blood pressure in patients with chronic renal failure and intractable hypertension and that plasma renin concentration and renin activity are increased in such patients before operation (see below). The present study has further shown that the circulating levels of angiotensin I and angiotensin II are also increased in these circumstances, that renin, angiotensin I, and angiotensin II fall in parallel after operation and that the extent of their decrease is related to the reduction of blood pressure. Measurements of renin and angiotensin may have practical value, therefore, in predicting the fall of blood pressure after bilateral nephrectomy in these circumstances.

The mechanism of the increased blood pressure in chronic renal failure is not established. One possibility is an abnormal interrelation of renin and sodium (see below). Excess sodium retention is probably a major factor in those patients whose blood pressure responds to removal of sodium. In unresponsive cases circulating levels of renin and angiotensin may be excessively high in relation to sodium status. This could have an anatomical basis in their renal disease (Brown et al., 1971, 1972). Therapeutic removal of sodium in an attempt to control blood pressure in these patients would result in an intense and inappropriate signal to renin release with rising levels of renin, angiotensin, and blood pressure. The situation would be worsened by further attempts to remove sodium. Bilateral nephrectomy may be successful in these circumstances because it removes the source of excess renin (Brown et al., 1971; Ledingham, 1971). The present results accord with this concept inasmuch as they suggest that the renin-angiotensin system is responsible for that element of hypertension in chronic renal failure which cannot be controlled by removal of sodium.
Mortality is high in patients with the intractable form of hypertension (Gavras et al. 1972) and, as emphasized previously, there may be a good case for undertaking bilateral nephrectomy at an early stage of the disease, particularly in cases suitable for renal transplantation (Wilkinson et al., 1970; Brown et al., 1971; Lazarus et al., 1972; Mahony et al., 1972).

With the exception of a study by Berman and his colleagues (1972) a renin-like enzyme has been consistently found in plasma after bilateral nephrectomy (Lever and Robertson, 1964; Toussaint et al., 1966; Blaufox et al., 1966; Capelli et al., 1968; Brown et al., 1969; Verniory et al., 1972; Yu et al., 1972). Observations by Capelli et al. suggest that the enzyme is in fact renin. Moreover, as judged by the relation between renin and angiotensin before nephrectomy, the reduced levels of angiotensin found after operation are appropriate to the reduced levels of renin (Figs. 1 and 2). Angiotensin is measured by radioimmunoassay and renin by bioassay, and it is unlikely, therefore, that non-specific material measured by one method would be measured also by the other. Circulating pepsin is an unlikely contributor to the pressor effect measured in the renin assay, since the substrate currently used in this laboratory does not react with pepsin to produce pepsitensin.

The persistence of renin in plasma for up to two years after bilateral nephrectomy (Fig. 5) strongly suggests an extrarenal source of the enzyme. Several organs yield renin-like material on extraction (Page and McCubbin, 1968; Genest and Koiw, 1972). The uterus and placenta are two (Stakemann, 1960; Gross et al., 1964), but they could not be the only source, since many of the patients with measurable levels of renin were male (Fig. 5).

We thank Professor $\mathbf{H}$. de Wardener for permission to report details of Case 4.

\section{References}

Berman, L. B., Vertes, V., Mitra, S., and Gould, A. B. (1972. New England Fournal of Medicine, 286, 58

Bianchi, G. et al. (1972). Clinical Science, 42, 47.

Blaufox, M. D., Birbari, A. E., Hickler, R. B., and Merrill, J. P. (1966). New England fournal of Medicine, 275, 1165.

Blumberg, A., Nelp, W. B., Hegstrom, R. M., and Scribner, B. H. (1967). Lancet, $2,69$.

Brown, J. J., Davies, D. L., Lever, A. F., Robertson, J. I. S., and Tree, M. (1964). Biochemical fournal, 93, 594 .'

Brown, J. J. et al. (1969). Nephron, 6, 329.

Brown, J. J. et al. (1971). British Medical Bulletin, 27, 128.

Brown, J. J., Fraser, R., Lever, A. F., and Robertson, J. I. S. (1972). In Clinics in Endocrinology and Metabolism, ed. A. Stuart Mason, vol. 1, p. 397. London, Saunders.

Capelli, J. P., Wesson, L. G., Aponte, G. E., Faraldo, C., and Jaffe, E. (1968). fournal of Clinical Endocrinology and Metabolism, 28, 221.

Dusterdieck, G., and McElwee, G. (1971). European fournal of Clinical Investigation, 2, 32 .

Investigation, 2, 32.
Gavras, H. et al. (1972). In Control of Renin Secretion, ed. T. A. Assay Keen. New York, Plenum Press.

Genest, J., and Koiw, E. (1972). Hypertension 1972, Berlin, Springer-Verlag.

Gleadle, R. I. et al. (1969). Proceedings of the European Dialysis and Trans-

plantation Association, 6, 131.
Gross, F., Schaechtelin, G., Ziegler, M., and Berger, M. (1964). Lancet, 1, 914.

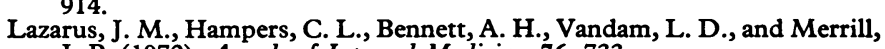
J. P. (1972). Annals of Internal Medicine, 76, 733.

Ledingham, J. M. (1971). Fournal of the Royal College of Physicians of London, 5, 103.

Lever, A. F., and Robertson, J. I. S. (1964). Fournal of Physiology, 170, 212.

Mahony, J. F. et al. (1972). Lancet, 1, 1036.

Onesti, G., Swartz, C., Ramirez, O., and Brest, A. N. (1968). Transactions. Amesti, G., Swartz, C., Ramirez, O., and Brest, A. N. (1968),
Ameciety for Artificial Internal Organs, 14, 361.

American Society for Artificial Internal Organs, 14, 361.
Page, I. H., and McCubbin, J. W. (1968). Renal Hypertension, Chicago, Year Book Medical Publishers.

Safar, M. et al. (1970). Revue Européene Ėtudes Cliniques Biologiques, 15, 740. Stakemann, G. (1960). Acta Pathologica et Microbiologica Scandinavica, 50,

350.
Stokes, G. S., Mani, M. K., and Stewart, J. H. (1970). British Medical

Fournal, 3, 126.
Toussaint, C. et al. (1966). Proceedings of the European Dialysis and Transplant Association, 3, 65.

Verniory, A. et al. (1972). Clinical Science, 42, 685.

Waite, M. A. (1972a). Fournal of Physiology, 222, 88P.

Waite, M. A. (1972b). Clinical Science, 42, 209.

Wilkinson, R., Scott, D. F., Uldall, P. R., Kerr, D. N. S., and Swinney, J. (1970). Quarterly fournal of Medicine, 39, 377.

Yu, R., Anderton, J., Skinner, S. L., and Best, J. B. (1972). American fournal of Medicine, 52, 707. 